\title{
Fazakas Emese Brassai Sámuel és a nyelvújítás
}

„Azt mondom hát, hogy a ki ezt a szót: nyelvújítás, legelőbb gyártotta, vagy fogalomba indította, annak észújításra lett volna szüksége" - írja Brassai Sámuel a nyelvújítás és Ballagi címü munkájában (különnyomat az Ellenzék-ből, Budapest-Kolozsvár 1881. 3), majd így folytatja: „Nem mintha alkata volna hibás - az ellen nem lehet kifogás, - hanem mivel egyáltalában nincs értelme: azaz oly concret fogalom, melyre jogosan lehetne alkalmazni, nem létezik. Háborút, fegyverszünetet, tisztséget, törvényt, rendeletet, szokást, szabadalmat, váltót, ismeretséget, barátságot, fájdalmat, panaszt, kérést, üdvözlést; eczetet, korpacziberét, czőköt megújíthatni: de hogy mind e kifejezésekből következtethető viszonyok melyikének az értelmében lehetne a szót, sőt a nyelvet »megújítani«, a ki ezt tudná, csak siessen közzétenni, mert én biz' addig azt állitanám, - sőt azután is, - hogy egyikében sem.(...) És méltán; mert Sprachneuerung volna, ha p.o. Az angol nép anglosaxonul, egész Irland keltaul, vagy Mexico honi eredetü lakói aztékul kezdenének beszélni. De mindezek mind nem történtek, $\mathrm{s}$ általában minden olyas tünemény, a cultura történelmében hallatlan!” (i.h. 3-4).

Az idézett résznek már az első mondata kritikus, a sokszor személyeskedésig menő Brassait tárja szemünk elé.

A múlt század második felében feléledt új ortológus mozgalom kiváltotta vitairatok Brassai Sámuel érdeklődését is felkeltették. Hisz az éles szemü kritikus, aki már megírta élete nagy nyelvészeti munkáit, és aki később a magyar nyelv „szánszándékos rontása (...), rombolása ellen” indítja meg a Magyar Nyelv Ellenőre címü lapot, nem hagyhatta figyelmen kívül az 1870-es években folyó neológus-ortológus vitát.

A nagy erdélyi tudós már előbb is síkra szállt az elburjánzó szóalkotások, magyartalan mondatok ellen. 1836-ban, a füvészet elveinek vázolata címü írásában az „ortológia és neológia közt helyes úton igyekszik haladni” (Tolnai Vilmos, a nyelvújítás. Budapest, 1929. 166). Helytelenítette a müszók szertelen szaporítását, de szükség esetén célszerünek mondja a jó szó alkotását. A szóalkotástól megköveteli, hogy 1.) egyezzék meg a jelölt tárggyal, s ne keltsen más meg nem felelő fogalmat; 2.) minél ismertebb a szó, annál jobb; tehát régi, népies szó eléje teendő a vadonatújnak; az újat ismert tőből képezzük; 3.) legyen állandó szava minden tárgynak, ne koholjunk egyre újat" (i.h 166). És húsz évvel később ugyanezen elvektől vezérelve bírálta Jósikát, aki korlátlanul fogadta be a nyelvújítást.

Ebben az időben Brassai több vitairatot, tanulmányt ír a nyelvújítás túlzásairól. Adalék okmányok a nyelvújitás és nyelvrontás ügyében címü cikkében, majd a magyar mondatról című tanulmányában, a puszta szóalkotásokon kívül már bőven foglalkozik a szó- és mondatszerkesztés szabálytalanságaival és idegenszerüségeivel is.

Az új ortológia a század hetvenes éveiben nyer nagyobb teret, amikor Szarvas Gábor a tudományos élet középpontjába kerül, és az Akadémia tagjává választja. Első akadémiai tevékenységei közé tartozik az, a Nyelvtudományi Bizottság feladatai közé sorolja a nyelv ellenőrzését és javítását. Hunfalvy, Budenz és Gyulai biztatására megindítja 1872-ben a Magyar Nyelvőrt, amelynek hasábjain bontakozik ki majd nagy mértékben az új neológusortológus harc. A vitát Szarvas akadémiai székfoglaló beszéde, a Latin fordítások és latinosságok váltotta ki. Hogy a nyelvmüvelés eredményesebb legyen, Szarvas Gábor 1874 végén intézményes szervezésre gondol, és a Nyelvőr hasábjain felszólítja a nyelv barátait, vegyenek részt közös tanácskozásokon, melyeknek célja „,(1) a visszásságok kimutatása, (2) a 
helyes magyarság megállapítása, (3) a közös megállapodás $\mathrm{s}$ a megállapított tételek elfogadása és terjesztése" (i.h. 184). Ezzel párhuzamosan, a Nyelvőr 1875-ben megjelenő IV. kötetétől Hibás szók és szólások javitása néven állandó rovat indul. „Kazinczy megtörte a Debreceni Grammatica zsarnoki dogmaticizmusát és felszabadította az író egyéniségét, Szarvas szigorú dogmaticizmusával a féktelen egyéniséget ismét fegyelemre szólította. De kihívta az ellentmondást is, és újra felgyújtotta az ortológia és neológia harcát, mely a hetvenes évek derekán lobogott legszenvedélyesebben, s azóta sem aludt ki teljesen" - írja Tolnai Vilmos 1929-ben (i.h. 185). Szarvas a nyelvújítás apológiája címú cikkében így jellemzi e korszakot: „A küzdelem nyelvújítás és nyelvjavítás között megkezdődött.” a küzdelem nemcsak Toldy Ferenc és Szarvas Gábor között folyik már, hanem 1875-től kezdve mindenki, aki a nyelv ügyét szívén viselte, szót kért a lapok hasábjain.

A Toldy - Szarvas-féle vita lezárása érdekében a Vasárnapi Újság ugyanezen év 18. számában, az „irodalom és müvészet” rovatban azt állítja az ortológiáról és neológiáról, hogy „szükség van mind a kettőre”. Tolnai Vilmos szerint ugyanez a békítő szándék vezeti Brassai Sámuelt is, amikor október 18-án felolvassa az Akadémián a neo-és palaeológia ügyében címü tanulmányát. Hogy mennyire volt az írás mögött békítő szándék, nem tudhatjuk. Azt azonban elmondhatjuk, hogy Brassai szavaiból ugyanazt olvashatjuk ki, mint amit Kazinczy jól ismert mondatából: „Jól és szépen az ír, aki tüzes orthologus és tüzes neologus eggyszer'smind,'s eggységességben és ellenkezésben van önmagával" ('Ortológus és neológus nálunk és más nemzeteknél' In: Fodor Irén szerk. A magyar nyelvújítás antológiája. Polis. Kolozsvár, 1995. 172). A kolozsvári tudós kimutatja mind a két pártnak az erényeit és hibáit, és a dicsérő, buzdító szavak mellett óva inti mindkettőt a túlzásoktól. Amint mondja, „nyelvphilosophia és társadalomtani tekintetben” kíván hozzászólni a dologhoz. „Alig van igazságtalanabb, balgatagabb, kártékonyabb panasz, illetőleg vád, mint az, hogy »szegény a nyelv«! Igazságtalan igenis, a magyar szó kiirthatatlan és elválaszthatatlan értelmében. És nemcsak e vagy ama kijelölt nyelvvel szemben, hanem egyáltalában, mert a föld kerekségén nincs szegény nyelv!" (Idézi Mikó Imre, Az utolsó erdélyi polihisztor. Kriterion. Bukarest, 1971. 147). Ezzel nemcsak azon neológusok ellen támad, akik a nyelvet szegénynek tartják és ezért újítanak, hanem ezáltal megfogalmazza azt a tételt is, amely szerint szegény nyelvről nem beszélhetünk, ha a nyelv megfelel közlö funkciójának. És ennek a funciónak hiánytalanul csak akkor felelhet meg, ha gyarapodása közben értelmességén és határozottságán nem esik csorba. A nyelv érthetőségét ugyanis kockáztatná a mérhetetlen és szüntelen újítás. Brassai csak a „tökélytelen” jelzőt tudja elfogadni, és a neológusok „szócsinálásában” éppen e tökélytelenség veszélyességét látja, hiszen a neológusok új magyartalan szavak létrehozásával akarják tökéletesíteni a nyelvet. Nyelvszegénység címen folyik a Magyar nyelvnek nem a gazdagítása, hanem az ,elnyavalyásítása”.

A neológusok hibái után az orotlógusokét sorolja. Különösen sérelmezi, hogy a Nyelvőr programja nem foglalkozik a mondattan kérdéseivel, pedig a mondat a beszéd alapja, és az új ortológusok nem hallgatnak az egészséges nyelvérzékre. Az akkoriban nagy teret nyert összehasonlító nyelvtudományt is támadja, amikor kijelenti, hogy a Nyelvőr rendezte közös tanácskozásokon résztvevők ,,a nyelvérzék elgyengülésében” sínylenek, „s ezt a bajt nem gyógyítja sem a török, finn, ugor, vogul grammatica, sem az altáji nyelvek összehasonlító rendszere" (i.h. 150). A nép nyelvére hívja fel a figyelmet, mondván, hogy Szarvas Gáborék hallják ugyan a népet beszélni, de nem értik.

Végső következtetésében ezt írja: „a palaeológia akarata jó, ügye szent, de eljárása rossz, célszerütlen, kártékony. A neológiának is meg kell adni, hogy jó volt az akarata, mert a nyelvet tökélyesíteni óhajtotta. De rossz volt az elve, mert a nyelvszegénység eszméjéből indulván ki, a tökélyesítést a magyar nyelv minden áron való gazdagításával akarta eszközölni (...) tanácsom ... ne gyújtsuk meg egyszerre mind a két végén a gyertyát, és ne akarjunk 
egyszersmind futni is, harapni is, ne pártoskodjunk, adjunk helyet az egyéni véleménynek" (i.h. 150).

Brassai ezen értekezésével maga ellen fordítja a neológusokat és az ortológusokat egyaránt. A neológusok közül Ballagi Mór írja meg véleményét Brassai és a nyelvújítás címen. Az ortológusok részéről Szarvas Gábor öt cikkében támad a Nyevlphilosophia ellen. A vita elmérgesedik, és Brassai sértetten válaszol a nyelvújítás és Ballagi címen a kolozsvári Ellenzékben. Hiszen Ballagi Brassainak éppen „A föld kerekségén nincs szegény nyelv” tételét cáfolja. Kifejti, hogy az elnyomott népek nyelve, akárcsak a magyaré, elszegényedett, és a neológiát nem a nyelvszegénység, hanem az idegen nyelven szerzett szavak sokasága hozta létre. Ballagi azonban nem áll meg itt, és a kolozsvári tudóst azzal vádolja, hogy az alaki logika híveként a nyelvfejlődésnek abban a szakaszában állt meg, amikor az aequatort ,a földet egyenlő részre osztó abroncs"-nak nevezték. Végül amellett foglal állást, hogy a nyelvet igenis meg kell újítani, szükség van az új szavakra, mert csak azok segítségével emelhetjük ,a házi tűzhely körében élő nyelvet a nemzeti nyilvánosság nyelvévé, a csekély számú avatottak közt tengődő irodalmat nemzeti irodalommá" (A nyelvújítás és Ballagi. Budapest-Kolozsvár, 1881. 12), és fel sem merülhet a kérdés, volt-e joga valakinek forradalmat csinálni.

Brassai válaszának bevezető szavaiban, melyet az előadás elején idéztem, személyeskedő hangnemet üt meg, és pár lappal tovább épp a Ballagi által használt forradalom szó ellen támad. Nem maga a szó jelentése zavarja, hanem a szövegkörnyezet. „Revolutiónak nem mondhatni, mert a nyelv szerkezetét nem változtatta meg. Mert ha egy nehány szabó saját szabású kabátot $\mathrm{s}$ nadrágot készítene és sikerülne nekik néhány száz emberrel megvétetni $\mathrm{s}$ elviseltetni, nem állítaná senki, hogy revolutio történt a szabómesterségben. De bizony forradalom vagy ... »nemzeti forrongás « se volt a neologismus, mert a nép nem csak nem vett részt benne, hanem eleitől fogva tiltakozott, hol passiva resistentiával, hol világos nyilatkozatokkal a szógyártók, mint a nyelv rontói ellen. Ellenben az, amit B(allagi) állít, hogy »a nemzet felkarolta az újításokat s magáénak vallotta, mert azokban saját szellemére, észjárására ismert«, merő költemény! S annál inkább valótlan, mivel az új szókat nem a »nemzet « kívánta, se nem annak a számára gyártották, hanem egyedül a fordítók kontár népségének volt szüksége reájok" (i. h. 11). A vita hevében úgy tünik, mintha Brassai az ortológusokkal értene egyet, s emellett a megütött hang sokszor az olvasóban azt az érzetet kelti, hogy az erdélyi tudós megfeledkezett állításai bizonyításáról. Pedig mindez benne van az értekezésben. Brassai sosem mulasztja el példákkal, magyarázatokkal alátámasztani állításait.

Kitér a tövek használatára, a képzők módosító erejére, a szóalkotás és analógia kérdésére, a „tájszógyüjtők éretlen ráfogásai”-ra, valamint a szószármaztatásra és a fordításra is. Ez utóbbit szükségesnek tartja. Csupán csak azt jegyzi meg, hogy „arra nem kell egyetlen új szó sem", azaz idegen, magyartalan szó, hiszen a magyar nyelv rendelkezik mindazokkal az eszközökkel, amelyek segíthetik a fordítót az új fogalmak megnevezésében. Kazinczy elveivel cseng egybe az a mondata, mely szerint „Az új szók csinálásáról lévén szó, nem egyszer sürgettem azt a szabályt, hogy a szónak olyannak kell lennie, hogy mívelt magyar ember, a ki az illető tárggyal ismeretes, ha csak a contextusból is, megérthesse szótár segélye nélkül” (i.h. 17). Brassai erre a következtetésre éppen a mondat tanulmányozása során jutott, hiszen azok, akik szembeszállnak vele, elszigetelték a szavakat, és nem vették figyelembe mondatbeli szerepüket, jelentésüket. Ellenben Ballagi vádja részben igaz, hiszen Brassai itt a 'képes' (vki képes valamit megtenni), valamint a 'évszázad', 'évtized' és 'évezred' szó helytelenségét bizonygatva, az alaki logika módszeréhez folyamodik. Az értekezés befejezéséhez egy latin idézetet választ, figyelmeztetve az olvasót, vigyázzanak a hamis prófétákra, akik szarvas képében jelennek meg ugyan, de az álarc alatt rabló farkasok. 
(,Attendite a falsos prophetis, qui veiunt ad os in vestimentis cervium intrinsecus autem sunt lupi rapaces" i. h. 35).

A támadások ellenére Brassai nem adja fel a harcot, és 1882-ben megindítja Kolozsváron a Magyar Nyelv Ellenőre címü lapot, amelyből csak két szám jelent, hiszen anyagi fedezet nélkül indult, és nem bírhatta a versenyt az Akadémia támogatásával megjelenő lapokkal, folyóiratokkal, mivel munkatársainak még tiszteletpéldány alakjában sem adhatott honoráriumot. A két számban megjelent cikkek közül érdemes idézni az Egy irodalmi pör pár sorát. „A nyelvőrista philosophiája ellenben olyan, mint a kimikus elemzése, amely élettelen, rideg anyagokat bont és rak össze, és nem gondol sem az egésznek, sem az elemek további müködéseivel, szervetlen kelmét kezel, s szervetlen lények keletkeznek mühelyében. Kritikája meg olyan a nyelvőristának, mint az anatómus bonckése, mely a holttesten szemmel megkülönböztethető szerveket fedez fel, s a szerveknek élö szerepe ismeretlen marad a boncoló tudós elött" (Mikó i. m. 157). Brassai tehát szerves lénynek tekinti a nyelvet, mint amely a gondolatok és érzelmek kifejezésére hivatott, $\mathrm{s}$ amelyet csak az emberrel kapcsolatban szabad vizsgálni. És ezt a szervességet felejtjük el ma is, amikor a nyelv használójától elvonatkoztatunk a nyelv vizsgálata közben. 